This item was submitted to Loughborough's Research Repository by the author.

Items in Figshare are protected by copyright, with all rights reserved, unless otherwise indicated.

\title{
Beyond the comfort zone: internal crisis and external challenge in the European Union's response to rising powers
}

PLEASE CITE THE PUBLISHED VERSION

http://dx.doi.org/10.1111/1468-2346.12038

\section{PUBLISHER}

John Wiley and Sons / @ The Author. @ The Royal Institute of International Affairs

VERSION

AM (Accepted Manuscript)

LICENCE

CC BY-NC-ND 4.0

\section{REPOSITORY RECORD}

Smith, Michael H.. 2019. "Beyond the Comfort Zone: Internal Crisis and External Challenge in the European Union's Response to Rising Powers". figshare. https://hdl.handle.net/2134/15005. 
This item was submitted to Loughborough's Institutional Repository (https://dspace.lboro.ac.uk/) by the author and is made available under the following Creative Commons Licence conditions.

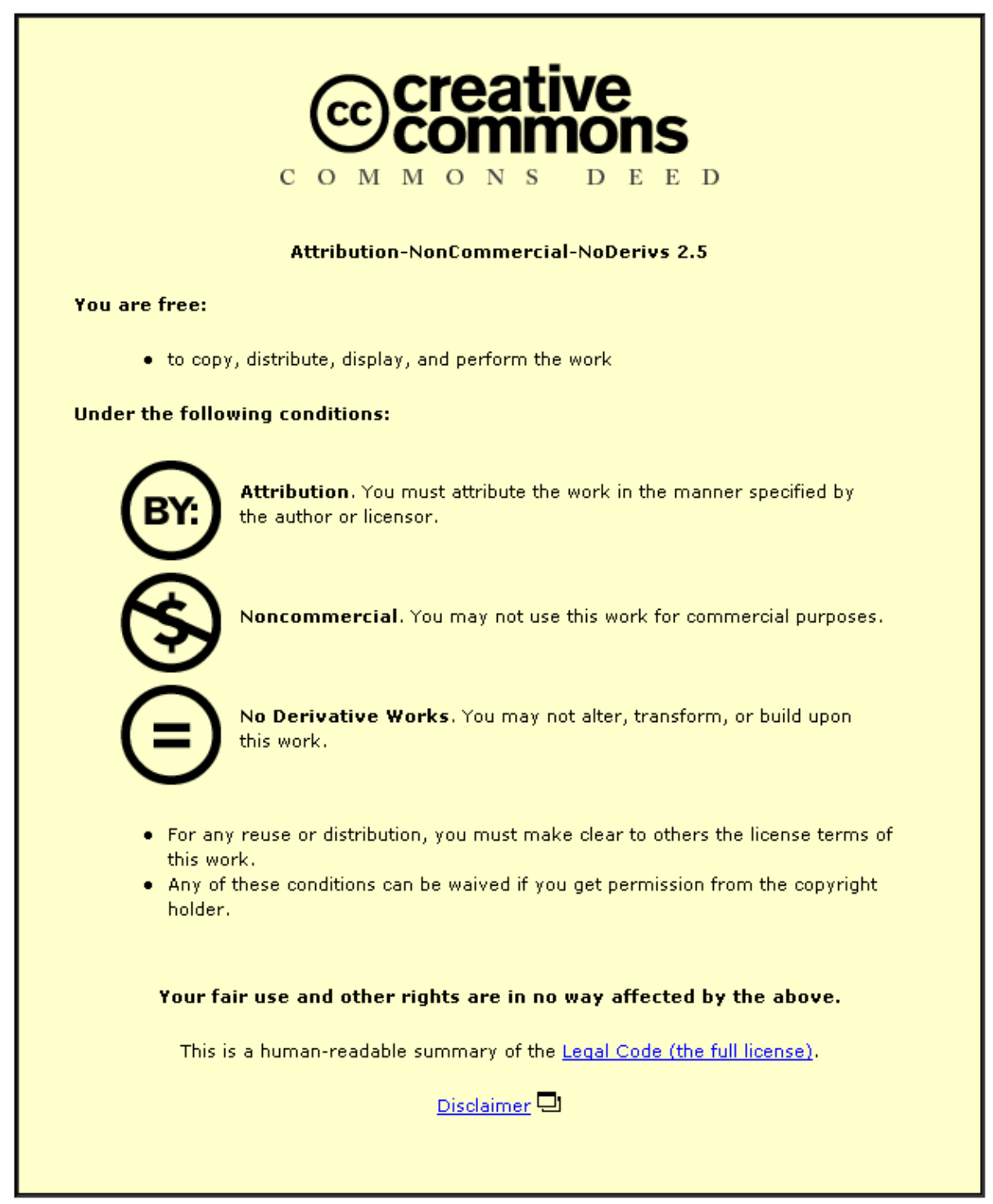

For the full text of this licence, please go to: http://creativecommons.org/licenses/by-nc-nd/2.5/ 
Beyond the comfort zone: internal crisis and external challenge in the European Union's response to rising powers

\section{MICHAEL SMITH}

How successful has the European Union been in recognizing and responding diplomatically to the challenge posed by rising powers, and what does this tell us about the status and role of the Union in international negotiation more generally? The argument in this article starts from three observations about the role of EU diplomacy in pursuing the Union's external interests. First, at least on paper, the EU has progressively equipped itself with the apparatus of a developed and comprehensive diplomacy, most obviously through the framing and then the implementation of the Lisbon Treaty. Second, that diplomacy has over the long term been directed predominantly towards the promotion and maintenance of negotiated order as a key approach to global governance and to the pursuit of the Union's interests. Third, this approach — the pursuit of global negotiated order through a wideranging EU diplomacy-is currently under major challenge from a confluence of internal and external forces, and thus the position of the EU in the overall framework of global governance and world order is open to question in ways that are effectively unprecedented. To put it bluntly, the Union is currently well outside its comfort zone and is likely to remain there for the foreseeable future.

These initial observations lead to a number of questions, which will guide the subsequent argument. First, how has the search for global negotiated order played into conceptions of the EU's diplomatic status and role? Second, how has the challenge to these conceptions arisen, and how can it be described, especially with reference to the roles of rising powers? Third, how has the EU responded to the challenge, and what are the key features of its response in policy and analytical terms? Fourth, what does the potential future for the EU's role in the promotion of global negotiated order look like, and what does this imply for the position of the European project in the future international order?

The argument in general is that the accumulation of diplomatic instruments by the EU has led over the past two decades to a set of assumptions about status and role that have guided the EU's quest for negotiated order in the world arena-and, incidentally, that this quest is a key feature of the EU's self-conception as expressed by Brussels policy-makers. These assumptions are now challenged internally not only by the effects of the financial crisis but also by a broader crisis of legitimacy and a narrower 
crisis of institutional capacity. At the same time, they are challenged externally by the rise of new powers, by pressures on the global institutions and principles of action that have in the past benefited the Union, and specifically by the rise of the BRIC countries. The challenge has been met with an uncertain response, discernible in a number of key areas of policy, and this in turn raises a number of important questions about the future of the EU's world order diplomacy.

This argument links strongly to the key themes set out in the guiding paper in this special issue by Amrita Narlikar. ${ }^{1}$ On the one side, it is clear that the EU can be conceptualized as an established power, which both supports and benefits from the established order in terms of global institutions and principles of international life. This in turn is a key factor in conditioning the EU's approach to global negotiated order, but for the EU there is an added dimension: the Union itself is a form of international negotiated order, and externally a form of emerging 'power', and this is vital to an understanding of its response to external challenges. ${ }^{2}$ In terms of its international practice, the EU sets great store by the refinement of international norms and institutional forms, and especially on the conduct of negotiations in institutionalized settings. As a consequence, the Union is heavily engaged in the promotion of negotiation strategies as a form of self-identification, in the attempt to frame international negotiation processes as a reflection of its own internal logics, and in the search for coalitions as a validation of its status in the world arena. This in turn has encouraged a view of the Union within the EU institutions as a potential leader in global negotiating processes, and as the progenitor of a certain style of diplomacy and negotiation, building on its internal deliberative and coalition-building processes. In this context, the rise of challenges both internally and externally is in some ways a bigger challenge for the EU than it is for other established powers, and some might go so far as to term the combination an existential challenge, penetrating to the heart of perceptions of the EU as an international actor. Whereas for other established powers the question is one of adjustment-sometimes wrenching — to new challenges, for the EU it is one of a different order.

\footnotetext{
1 'Negotiating the rise of new powers': see pp. 000-00 above.

${ }^{2}$ See Michael Smith, 'The European Union and international order: European and global dimensions', European Foreign Affairs Review 12: 4, 2007, pp. 437-56.
} 
The article proceeds to investigate these issues as follows. First, it explores the ways in which the EU's search for international negotiated order reflects central features of its status and roles as a diplomatic actor. Next, it assesses the nature of the external challenge from rising powers and the questions they raise about the context for EU external action. It goes on to evaluate the nature and effectiveness of the EU's response to the challenge, focusing on bilateral, interregional and multilateral aspects and relating these to a number of key EU concerns: security, commercial policy, development, environment and energy. The final section of the article returns to the general issues raised in this introduction, and to possible futures for EU diplomacy in the context of the changing world order. It should be noted at this point that the focus of the argument is strongly on the EU, but that at a number of junctures the question of 'Europe' more broadly, and of the negotiating orientations of EU member states in particular, will be addressed; indeed, this is part of the argument—and a source of questions-about the EU's status and role in the generation of international negotiated order.

\section{Diplomacy, status and role in EU external relations}

There is a very large and growing literature on the nature of the EU as an international actor, and this has become one of the litmus tests of the development of the European project. The purpose here is not to dwell on these often rather abstract approaches, but to draw attention to four key aspects of the EU's approach to diplomatic processes and practices in the world arena, and to lay the basis for an understanding of the challenges to which these are now subject.

The first aspect relates to the nature of EU diplomacy itself. This is a long-established and multidimensional aspect of the European project. In fact, there are several strands to the development of the EU's system of diplomacy, and it is important to recognize these here since their existence contributes to the current predicament that faces the Union. In the first place, there is a well-established strand of commercial diplomacy, resting on the common commercial policy as progressively extended and consolidated in successive treaties, and expressing the 'Community method', reflecting exclusive competence for what used to be 'pillar one' institutions and actors. ${ }^{3}$ Secondly, there is an almost equally long-established strand of development diplomacy, focusing on the

\footnotetext{
${ }^{3}$ See Stephen Woolcock, European Union economic diplomacy: the role of the EU in external economic relations, (Aldershot: Ashgate, 2012).
} 
successive conventions and frameworks that most recently produced the Cotonou Convention; this is an essentially mixed system of diplomacy, in which the interests and institutions of member states coexist with the resources and practices of EU institutions. ${ }^{4}$ More recently, the same type of mixed policy-making process and diplomatic activity can be observed in areas such as environmental policy. ${ }^{5}$ Finally, there is the strand of diplomatic coordination among member states, most obviously expressed in the Common Foreign and Security Policy (CFSP) and embodying intergovernmental collaboration, albeit within an increasingly dense set of 'European' institutions and practices. ${ }^{6}$

These three strands of EU diplomacy continue to exist despite the Lisbon Treaty's attempts to set them within the framework of a broad 'external action' framework, and some of the problems of implementing $\{\mathbf{1}\}$ the treaty stem precisely from the robustness and vigour of the pre-existing lines of policy and institutional commitments. The EU's external action is an essentially hybrid construct, and will continue to be so; ${ }^{7}$ this has led to a couple of years of interinstitutional frictions and wrangling since the initiation of the European External Action Service (EEAS) in 2011\{2\}, and to constant challenges of adjustment and institutional boundarydrawing, centring on the role of the High Representative for Foreign and Security

${ }^{4}$ See Maurizio Carbone, The European Union and international development: the politics of foreign aid (London: Routledge, 2007); Martin Holland and Mathew Doidge, Development policy of the European Union (Basingstoke: Palgrave Macmillan, 2012).

${ }^{5}$ See e.g. Rüdiger K. W. Wurzel and James Connelly, eds, The European Union as a leader in international climate change politics (London: Routledge, 2011).

${ }^{6}$ Michael E. Smith, Europe's foreign policy: the institutionalization of cooperation (Cambridge: Cambridge University Press, 2003).

${ }^{7}$ For a discussion of the concept of hybridity as applied to EU external relations, see Michael Smith, 'Still rooted in Maastricht: European Union external relations as a “third-generation hybrid”', Journal of European Integration, 34:7, 2012, pp. 699-716; Michael Smith, 'The European Union as a diplomatic actor in the post-Lisbon era: robust or rootless hybrid?', in Joachim Koops and Sebastian Oberthür, eds, The European Union as a diplomatic actor: policies, processes and performance (Basingstoke: Palgrave Macmillan, forthcoming 2013). 
Policy/Vice-President of the Commission (HRVP) vis-à-vis the President of the Commission and the President of the European Council. As a result, the institutional context for EU diplomacy has remained uncertain, as has the more material dimension of institutional resources and capacity. ${ }^{8}$

But this is not the whole of the story. The tendency to focus on the institutional framework and institutional fixes as the mark of progress in EU external action misses a major — indeed, it might be argued, the predominant—aspect of the political context. If diplomacy, embodying key processes such as deliberation, representation, communication and negotiation, is to be effective, it must be practised on the basis of stable political preferences and a shared understanding of the ends of the action undertaken. In short, there must be a shared strategic sense-not necessarily in the shape of a 'grand strategy', but in the shape of a shared narrative of what diplomacy is about and what it is aimed at achieving. Only then does the deployment of resources, the conduct of negotiations and the evaluation of progress become possible. The problem in today's EU is that this shared strategic sense is difficult to discern, although there are areas, such as trade policy, in which it is more salient. ${ }^{9}$ In particular, there is little sense of leadership, and as a result there is a problem of legitimacy. In large part, this is a reflection of the ways in which internal crisis has affected the diplomatic context for EU external action, but it also reflects halting responses to a number of major external challenges. The two dimensions are interlinked, and they will be explored further below.

Uncertainty about the institutional and political foundations for EU diplomacy links strongly to a second key aspect of the EU's international life: the question of the EU's status, and the question of whether it can operate as a 'power' in the world arena. ${ }^{10}$ All sorts of labels have been attached to this: 'civilian power' (and by extension

\footnotetext{
${ }^{8}$ See Brian Hocking and Michael Smith, 'An emerging diplomatic system for the EU? Frameworks and issues', Cuadernos Europeos de Deusto 44\{?\}, 2011, pp. 19-42; also Sophie Vanhoonacker, Karolina Pomorska and Petar Petrov, eds, 'The Emerging EU Diplomatic System', special issue of The Hague Journal of Diplomacy, 7:1, 2012\{?\}. ${ }^{9}$ See Woolcock, European Union economic diplomacy.

${ }^{10}$ See Christopher Hill and Michael Smith, eds, International relations and the European Union, 2nd edn (Oxford: Oxford University Press, 2011), introduction and conclusion.
} 
'civilizing power'), 'normative power', 'force for good', 'structural power' and so on. Many of these labels have not just an empirical content but also a normative dimension-the EU not only represents a certain weight of power, but also possesses a certain set of ideas and values that mark it out as distinctive. Most recently, there has been discussion of the extent to which the EU can be conceptualized as a 'great power' within an emerging system of great powers, ${ }^{11}$ and of the notion that, conversely, the EU is in key behavioural respects a 'small power' ${ }^{12}$ In these conceptualizations, the notion that the $\mathrm{EU}$ is somehow different is related quite strongly to the demands faced by and implicit standards required of an actor at a certain level of international status and influence- that is to say, the norms are driven by status, not status by the norms. In this context, however, it is clear that there are tensions: the EU is almost universally conceptualized as a 'post-Westphalian’ or 'post-sovereign' form of international actor, but has to establish its status in an environment in $\{3\}$ which there is a persistent strand of 'sovereignist' diplomacy, emerging not least from the rising powers. One way of attempting to square this circle is to deploy the notion of the EU as a 'trading state', which puts the emphasis more on a functional evaluation of what the EU's key areas of interest might be and the kinds of behaviour and preferences that would then follow-a preference for multilateralism, for negotiation and above all for stability as the key requirement for the successful pursuit of commercial advantage. ${ }^{13}$ A key implication of this conceptualization is that it has enabled the EU over a long period to distinguish itself from the United States, in terms of both values and diplomatic practice. ${ }^{14}$ The US

${ }^{11}$ See Andrew Moravcsik, 'The European Union as a quietly rising superpower', in Alan Alexandroff and Andrew F. Cooper, eds, Rising states, rising institutions: challenges for global governance (Washington DC: CIGI/Brookings Institution, 2010).

${ }^{12}$ Asle Toje, 'The European Union as a small power', Journal of Common Market Studies 49: 1, Jan. 2011, pp. 43-60.

${ }^{13}$ Michael Smith, 'Between two worlds? The European Union, the United States and world order', International Politics 41: 1, 2004, pp. 95-117.

${ }^{14}$ Michael Smith, 'European Union responses to US diplomacy: 'special relationships', transatlantic governance and world order', The Hague Journal of Diplomacy, 6:3-4, pp. 299-317. 
embodies in many ways a 'sovereignist' approach to international action, in contrast to the 'post-sovereign' or 'post-Westphalian' approach associated with the EU. The real problem, though, is that the EU corresponds to all and none of the above (and other) labels. A key fact of its international life is that its status is still uncertain. One obvious related fact is that while the $\mathrm{EU}$ is what some might describe as a 'commercial superpower', in other areas of its external action it is decidedly stunted. For the EU, this creates a problem of coherence and consistency, which is underlined by the interinstitutional problems that persist even after (or because of?) Lisbon. ${ }^{15}$ For those affected by the EU's internal and external actions, it can create an unnerving kind of disparity in which one day the Union can appear predominant if not hegemonic, and the next day on a different issue it can appear marginal. In earlier times, this might have been described in terms of 'rank disequilibrium', the phenomenon that means that individuals and groups have to wrestle with markedly different valuations of their potency and effectiveness in often closely related areas of social activity. This means that any attempt to categorize the EU as one type of 'power' or another can rapidly come to grief, both when measured against the inconsistencies of EU action itself and when measured against external expectations and impact.

This is of course a variant of what Christopher Hill described as the 'capabilitiesexpectations gap'-a problem not suffered uniquely by the EU, but certainly suffered in a distinctive way. ${ }^{16}$ In reality, there is not one such gap, but a series of gaps, broader or narrower, depending upon the areas of activity that are under examination. In the context of the argument here, a key element of this situation is that the EU operates over a wide range of diplomatic 'sites', each with its own specific features and its own challenges to the EU's aspirations and resources. Crucially, a key component of this problem is not simply the expectations of outsiders in relation to

\footnotetext{
${ }^{15}$ See Carmen Gebhard, 'Coherence', in Hill and Smith, eds, International relations and the European Union, pp. 101-27.

${ }^{16}$ Christopher Hill, 'The capability-expectations gap, or conceptualising Europe’s international role', Journal of Common Market Studies 31: 3, 1993, pp. 305-28; Christopher Hill, 'Closing the capability-expectations gap?' in John Peterson and Helene Sjursen, eds A common foreign policy for Europe? Competing visions of the CFSP (London: Routledge, 1998), pp. 19-39.
} 
EU action, but the role conceptions and thus the expectations of those inside the EU, specifically those in the Brussels institutions. This means that the third aspect of EU external action to be examined here, that of the EU's role, is in part a reflection of the uncertain internal balance of power and preferences noted above. Studies of role in international politics distinguish between three aspects of role in broad terms: role conception, role performance and role evaluation. ${ }^{17}$ It should be clear from what has been said already that the EU faces issues in all three of these areas. Role conceptions are framed not only in Brussels but also in national capitals, and then shaped by external forces; role performance is subject to institutional and capacity limitations, and will vary widely from issue area to issue area reflecting the status uncertainties and resource issues noted above; role evaluation will reflect not only an objective measure of performance but also the political and normative debate about the ways in which the Union itself ought or ought not to develop.

The result is that the EU embodies a set of paradoxes. It is often presented as a compulsive multilateralist, setting as the standard of its performance the achievement of 'effective multilateralism' and actively expressing its role as a key stakeholder in the multilateral system. But at times it can act as an insular power, reflecting the dominance of internal bargaining and the stalemate that can ensue. At other times it can act as a practical unilateralist, reflecting the predominance of internal needs and the power of the self-conception of the Union as a different type of 'power'. Such contradictions in role are not unique to the EU, but they have a special impact on the Union's external action given the intense linkage between internal negotiation and external behaviour. So the commitment to 'effective multilateralism' does not mean that the Union is an effective multilateralist, and similar commitments such as that to the Union as a 'force for good' are not always fulfilled in the harsh light of political and commercial imperatives. One of the most important areas in which these paradoxes can be discerned is that of leadership and followership: is the EU capable of providing leadership as a global public good, or is it limited to following where others have already made the commitment and borne part of the costs? This brings us to the final aspect of EU external action to be examined here: the pursuit of negotiated order in the world arena. In one sense, this is a simple

\footnotetext{
${ }^{17}$ See Ole Elgström and Michael Smith, eds, The European Union's roles in international politics: concepts and analysis (London: Routledge, 2006) introduction.
} 
externalization of the commitment to internal negotiated order within the Union: this is the key way in which member states and others are engaged with the European project, through a process of intense transgovernmentalism, and it makes perfect sense for it to be the organizing principle of EU external action. To use the definitions put forward by Amrita Narlikar in her framing essay, the presumption would be that the EU, externally as well as internally, would be committed to negotiating strategies based on deliberation and the active pursuit of coalitions, and to integrative and valuecreating negotiations, since those are what has served the project well through its half century and more of existence. In the world arena, this creates a natural preference for the creation of rules and regimes, expressed through processes of continual negotiation and aimed at the creation or enhancement of global public goodswhether these are defined in terms of security, welfare or the promotion of global values. ${ }^{18}$ Further, this preference clearly serves the need of the EU and its institutions for recognition as a major international actor: engagement in global negotiations is a significant contributor to the credibility of the Union as a diplomatic presence. As noted above, this position can be distinguished quite sharply from that of the United States, but clearly it is also important to note that both the EU and the US can be seen as 'established powers' in the sense used by Narlikar, given that both are major stakeholders in the existing order and institutional configuration.

This commitment to negotiated order in the world arena remains at the core of EU external action. But, as can be seen from the argument in this section, it is currently under severe challenge. The security of the EU order is questioned, and the ability of EU member states and institutions to provide leadership within the Union is open to

\footnotetext{
${ }^{18}$ For general discussions of the role of negotiation and negotiated order in EU policy-making and external relations, see Ole Elgström and Michael Smith, 'Introduction. Negotiation and policy-making in the European Union: processes, system and order', Journal of European Public Policy 7: 5, 2000, pp. 673-83; Ole Elgström and Christer Jönsson, eds European Union negotiations: processes,
} networks and institutions (London: Routledge, 2005). On the differences between EU and US approaches, see e.g. Michael Smith, 'The European Union, the United States and global public goods: competing models or two sides of the same coin?', in Richard Whitman, ed., Normative power Europe: empirical and theoretical perspectives (Basingstoke: Palgrave Macmillan, 2011). 
doubt. Negotiations over the sovereign debt crisis have struggled to appear committed to integrative and value-creating outcomes, and have raised fundamental questions about the internal balance within the European project. The extent of internal contestation might be assumed to have crucial effects on the EU's ability to respond to external challenge, and to create major questions about the legitimacy and efficacy of the EU's responses, once framed. ${ }^{19}$ In order to pursue this proposition, we need first of all to be clear about the nature of the external challenge itself, and this is the subject of the next section.

\section{The challenge of rising powers}

The shaking of the EU's internal foundations has been accompanied by a rising sense of external challenge from new actors and new issues, especially in connection with the emergence of new groups of 'powers' in the world arena. ${ }^{20}$ The two are of course not unconnected, and we will return to that relationship later. But here the purpose is to identify as clearly as possible the ways in which the challenge of rising powers makes itself felt for the EU, as a preliminary to exploring the EU's responses. This section will look first at the nature of the changing world arena and the opportunities or constraints it offers for the EU, then at the specific challenge of the BRIC countries, and then at the ways in which this challenges the EU's system of diplomacy. It will conclude by asking what might be expected in the way of an EU response to this set of challenges.

One key facet of the external challenge to the EU's diplomacy lies in what might be described as the international opportunity structure. The world arena has arguably moved from a post-Cold War structure (1990-2001), through a 'post-post-Cold War' structure (2001-2008) to a 'post-post-post-Cold War' structure (2008 onwards): the first defined by the collapse of the Soviet Union and the unipolar predominance of the United States, the second by challenges to the US and recognition of the limitations of

${ }^{19}$ See the arguments in Giovanni Grevi and Thomas Renard, eds, Partners in crisis: EU strategic partnerships and the global economic downturn (Brussels: Academia Press for the European Strategic Partnerships Observatory, 2012).

${ }^{20}$ See the other articles in this special issue of International Affairs; also Alexandroff and Cooper, Rising states, rising institutions; Thomas Renard and Sven Biscop, eds, The European Union and emerging powers in the 21st century: how Europe can shape a new global order (Aldershot: Ashgate, 2012). 
its power in specific conflict situations, the third by the emergence of rising powers and their much more active (re-)engagement in world affairs. Viewed in these terms, the world arena has provided major opportunities for the EU to develop a diplomatic presence and to maximize its diplomatic impact, but also major constraints on its ability to do so. ${ }^{21}$ Most obviously, the post-Cold War period enabled the EU to lead the restructuring of Europe through enlargement, despite some notable short-term failures in situations involving hard power and violence, and the post-post-Cold War period enabled the EU to position itself as a 'power' in terms of broader security structures and the generation of values on which a response to the challenges of terrorism or environmental degradation could be based. The post-post-post-Cold War period, though, has seen a major politicization or securitization of new areas of international life, in which the EU has struggled to adjust to a new geopolitics (for example in Africa) and in which the rising powers have taken a major role. This, though, has not been the whole of the story. A focus on security and on the distribution of aggregate power reveals a lot about the potential and limitations of the EU's diplomatic presence, but in terms of the EU's engagement with the world arena it is if anything a minor part of the picture. The major part is the EU's engagement with the world political economy, in areas where it has a very long-established diplomatic presence and where it has been a key player for decades. ${ }^{22}$ Seen in this light, the entire post-Cold War period is one in which the implications of globalization have been partly realized but also one in which regionalization and a shift in the location of economic power and potential have taken place. If one sees the EU as a 'trading state', this is the area of maximum significance for the external strategy of the Union, since it has placed successive pressures on each of the key elements of a trading state strategy: multilateralism, negotiation and stability. The impact of globalization and of interconnectedness between theoretically separate national or regional economies has created new insecurities, and the speed of international transactions has accentuated both these and the shifting pattern of advantage or disadvantage, making it far more difficult to conduct long-term framework negotiations in a multilateral context. This has combined with the emergence of new

\footnotetext{
${ }^{21}$ See Renard and Biscop, eds, The European Union and emerging powers, esp. Part 1 .

${ }^{22}$ Woolcock, European Union economic diplomacy.
} 
regional concentrations of economic power and potential to change the pattern of supply and demand in the global economy and to create new chains of production and exchange that in principle demand new forms of regulation (but in practice create new obstacles to precisely such attempts at regulation). Finally, the shift in power distribution has had effects both within multilateral institutions and negotiating contexts and within key regions, putting new pressures on those who would wish to retain or reinforce the existing regulatory structures. The continuing stalemate in the Doha Round of world trade negotiations is emblematic of this convergence of processes and pressures.

What does this imply for the opportunities available to or the constraints experienced by the EU? While it is possible to define these in relatively clear-if not always encouraging - ways in the realm of security, it is much more difficult in the sphere of political economy. Back in the early 1990s, an argument was made by Lester Thurow and others that the EU would 'rule the 21st century' by virtue of its proven capacity to manage and regulate a continental-sized economy, ${ }^{23}$ but this has turned out to be an illusion. To be sure, during the 1990s there was a moment when the EU appeared to be the effective leader of the multilateral trading system (especially when the 'holy trinity' of the IT agreement, the telecoms agreement and the financial services agreement came together in the later part of the decade) and the development assistance system (in the run-up to the Cotonou Convention), and when this dominance appeared likely to extend to environmental affairs through the EU's pursuit of ratification of the Kyoto Protocol. Significantly, during this period the United States was seen as more of a problem for multilateralism and global governance than as part of any potential solution. But more recently, the EU model has been challenged in Europe itself, as a result of the pervasive and destabilizing effects of globalization, most specifically through the financial crisis since 2008 but also through the stalling of such policies as the emissions trading system and the search for Europe-wide energy security. At the same time, it has been challenged outside Europe by the emergence of new powers with new preferences about the appropriate management structures for global production and exchange. The EU has entered into this process, but it has been scarred by it in the Doha Round and

\footnotetext{
${ }^{23}$ See Lester C. Thurow, Head to head: the coming economic battle among Japan, Europe and America (New York: Morrow, 1992).
} 
elsewhere. Not least, of course, it has been damaged by the revelations of its own vulnerability in the light of the eurozone sovereign debt crisis.

The shorthand conclusion of this discussion is that in terms of the changing global arena broadly defined, the EU has experienced an opening up of opportunities through the 1990s, but then a progressive closing down during the first decade and more of the new century, as a result of the internal and external constraints noted above. We shall return to this set of issues later when discussing the EU's response, but the picture in general terms now needs to be supplemented by an exploration of the specific challenges posed by emerging powers, and especially the BRIC countries. The EU has faced challenges from emerging powers before-perhaps most obviously from Japan and then Korea and the 'Asian tigers' in the 1970s, 1980s and early 1990s — and in those cases responded through a mixture of internal reform through the Single Market Programme, external regulation through bilateral agreements and outright protectionism, and multilateral rule application through the GATT. These targets of EU policies, while often the source of suspicion, were also rather obliging: they wanted to take advantage of the multilateral benefits to be gained from the GATT, and they did not want to challenge the principles of the multilateral system itself. They could also be dealt with in many respects on an arm's length basis, since at that point they posed predominantly an external rather than a transnational challenge. And they did not bear with them any major implications for the management of global security and stability.

The current challenge is by no means so easy to deal with. Although much of the attention has focused on the BRICs, this grouping is only one manifestation of a sometimes dizzying proliferation of new groupings within the world arena, starting with the BASICs and encompassing regional organizations as well as individual 'great powers'. ${ }^{24}$ So the challenge is one of diversity and thus of differentiation between the various constellations, and one that links specific issues with specific

\footnotetext{
${ }^{24}$ For discussions of this diversity, see Stephan Keukeleire and Hans Bruyninckx, 'The European Union, the BRICs and the emerging new world order' in Hill and Smith, eds, International relations and the European Union, pp. 380-403; Stephan Keukeleire and Jennifer MacNaughtan, The foreign policy of the European Union (Basingstoke: Palgrave Macmillan, 2008), ch. 11; Renard and Biscop, eds, The
} European Union and emerging powers. 
negotiating 'sites' and specific coalitions. Second, the challenge is of much greater scale than that of the 1970s and 1980s: the countries concerned are (or are in the process of becoming) the world's largest producers of some commodities and products, and are often also the largest consumers of important raw materials-some of which are particularly sensitive for the EU. One concomitant of this is the BRICS' increasing interest in and engagement with areas such as sub-Saharan Africa in which the EU has previously considered itself to have a leading position, both in terms of development and in terms of security. Third, the BRICs especially are taking an increasingly activist position on the nature of global governance and the reform of the multilateral system, and they take markedly divergent positions on many institutional issues from those adopted by the EU (and the United States). In respect of the EU in particular, these positions reflect the underlying issue noted earlier-the European pursuit of a 'post-sovereign' diplomacy and approach to governance in a world where many actors are resolutely 'sovereignist' in their approaches. Whereas previously this challenge could be managed because the major 'sovereignist' actor, the United States, shared strategic commitments and underlying values with the EU in many areas, and others such as Japan were not inclined to be assertive, neither of these conditions applies now. The rising powers are (with variations) 'sovereignist', committed to diverse values and inclined to be assertive. Finally, the challenge is one that links welfare and security in crucial ways: the issues of energy security, environmental security and human security are raised in different ways by different emerging powers, but they are inseparable from the challenge as a whole.

What does this mean for the EU and its efforts at external action, in particular its construction of a system of diplomacy to bring together its external policies? The rise of the new 'great powers' is an external shock for the Union, but it is one of a slowburning kind that will be punctuated by other short-term shocks and perturbations. Its course is so far difficult to predict, and as a result there is a pervasive uncertainty (not just in the EU) about its implications for international structures, and for the status and role of the Union. This is supplemented in many areas by a parallel uncertainty about the position and the role of the United States, which has found it difficult to adjust to changes in its domestic and its external environments. A key question for the EU is whether the new incompletely multipolar system will also be one in which principles of multilateralism hold sway; to the extent that they do, the EU could be said still to be in the same game as it always has been, but to the extent that they 
don't, the EU will be challenged particularly sharply. To put this in practical terms: in dealing with new challenges in East Asia, the EU has a range of potential multilateral or interregional approaches, but the United States has many more, arising out of its status as a leading 'power' of the traditional kind, and there are resulting difficulties in trying to frame an approach that could engage both the EU and the US in pursuit of common goals. ${ }^{25}$ Such EU-US cooperation might be seen as a logical consequence of the increasing difficulties faced by international cooperation in general, but even if possible it may not be enough to reinvigorate cooperation at the global level. The brute fact is that in the presence of the rising powers, such broader cooperation is not possible without their support-or at least, the support of a majority of them-and the quest for such support comes up against precisely the diversity and fluidity of values and interests identified earlier.

One central challenge will be precisely to the EU's emerging system of diplomacy as outlined earlier in the paper. The nature of the challenge from rising powers is one of a scope, scale and variety not experienced by the Union at any point in its existence. It links security and welfare considerations in novel and potentially threatening ways. And it has major implications not only for the Union as a collective, but also for key EU member states, who experience security and commercial challenges and opportunities at a national level as well as through the mediating influence of Brussels. To coin a phrase, this challenge requires a full-spectrum diplomatic response, with the capacity to link and fruitfully integrate responses in a variety of areas and at a variety of levels. But we have already seen that the diplomatic system of the EU remains fragmented, that there are internal challenges to be overcome, and that the overall structure of the world arena is one in which arguably the 'space' for effective EU diplomacy has been closed down.

How might this shape EU responses to the challenge of rising powers? In the light of what we have already said about the linkages between the internal and external dimensions of the EU's external action, we might expect some or all of the following responses. In the first place, the EU could engage in a large-scale search for international strategic frameworks as a means of containing the challenge, of

\footnotetext{
${ }^{25}$ See Patryk Pawlak, ed., Look east, act east: transatlantic agendas in the Asia Pacific, report no. 13 (Paris: European Union Institute for Security Studies, Dec.
} 2012). 
maintaining multilateral principles and of stabilizing the EU's environment. This would be an essentially defensive response, aimed at preserving the gains made by the Union from the existing structures and processes. Such a general response and accompanying actions would demand a multi-level differentiated diplomatic strategy, with a concomitant need for coordination and linkage to give it effect and to evaluate its impact—but there would be internal and external uncertainties about how this response might be articulated and implemented. One such area of uncertainty might be the emergence of significant problems arising from institutional fragmentation, from the activism of member states, and from the patchy nature of leadership and legitimacy within the EU system. This set of problems could well be accompanied by issues arising from lack of capacity and resources within the system, coupled with an inability to respond rapidly and effectively to changing circumstances.

The next section will explore the nature and extent of the EU's response to the BRICs within this context, before the final section provides an overall evaluation of the EU's diplomatic responses.

\section{The EU's response: still searching for negotiated order, but in a changed world}

As noted earlier, the search for negotiated order in the world arena has been the centre of the EU's diplomatic efforts—not just since the Lisbon Treaty, not even since the end of the Cold War, but since the early days of the European project. In this quest, the EU has deployed a number of lines of action-bilateral, interregional, multilateral — and as a result it is possible to talk of an inventory of methods by which the EU has pursued negotiated order. It has also deployed these methods in distinctive ways, not least because the Union has very little weight in certain areas of the diplomatic spectrum. To be specific, the EU's system of diplomacy is hardly at all linked to the possible deployment of hard power, although this does not rule out the use of a number of coercive measures, such as economic sanctions, in pursuit of the broader principles of negotiated order. In this section, the discussion centres on the inventory mentioned above, and on the ways in which it has been used in relation to rising powers. The discussion attempts to make explicit some of the implications of the ways in which the EU has responded to rising powers, and to illustrate this by reference to the key issues mentioned earlier: security, commerce, development, environment, energy.

The first set of measures that the EU has used in its response to rising powers consists of bilateral negotiations and frameworks. Indeed, one of the key elements of the EU's 
bilateral approaches to rising powers has been the attempt to create frameworks within which such powers might be contained and the dynamics of the relationships managed in a way that is comfortable for the Union. One of the key features in this area has been the EU's pursuit of strategic partnerships: each of the BRIC countries has been engaged by the Union in negotiations designed to create a set of principles for such a partnership, to develop an infrastructure of dialogues and sectoral working relationships, and to enmesh the 'target' ever more fully within a dense set of institutionalized links that would render the costs of defection higher than they otherwise might have been. Such partnerships have also been explicitly linked to the EU's pursuit of 'effective multilateralism' and to the broader desirability of commitments to global governance processes. ${ }^{26}$ From an 'internal’ EU perspective, these strategic partnerships have been part of the means by which the EU has attempted to establish itself as an interlocutor at the highest levels in the world arena, and thus a means by which the EU's role conception as a major but distinctive type of power can be promoted. From an external perspective, in addition to the points made above, the notion of strategic partnerships has paralleled moves by the United States to refashion its bilateral relationships with key emerging powers, but it has been carried out without the baggage of hard security concerns that have provided a continuing set of frictions for the US in its relationships with all the BRICs. The record of these EU-initiated strategic partnerships, however, is patchy, and the concept has itself become diluted and open to question. ${ }^{27}$ In relation to the BRIC countries in particular, Brazil, Russia, India and China have each been declared by the

${ }^{26}$ See Giovanni Grevi and Alvaro de Vasconcelos, eds, Partnerships for effective multilateralism: EU relations with Brazil, China, India and Russia, Chaillot Paper no. 109 (Paris: European Union Institute for Security Studies, 2008).

${ }^{27}$ See e.g. Thomas Renard, The treachery of strategies: a call for true EU strategic partnerships, Egmont Paper no. 45 (Brussels: Egmont, Royal Institute of International Relations, April 2011); David Allen and Michael Smith, The EU, strategic diplomacy and the BRIC countries, Policy Paper no. 11, Jean Monnet project on 'The diplomatic system of the European Union: evolution, change and challenges', Feb. 2012, http://dseu.lboro.ac.uk/Documents/Policy_Papers/DSEU_Policy_Paper11.pdf , accessed $8^{\text {th }}$ April 2013. 
EU to be a strategic partner, but in each case the scope and depth of the partnership achieved have been open to question. Sometimes this has been a reflection of the unevenness of the EU's interaction with the countries concerned: in most cases, the predominant element of the partnership is commercial collaboration, but these are countries with which the EU has also had a good deal of competitive tension, and which have exposed the relative vulnerability of key sectors in the European economy. A key illustration in this case is that of relations with China in such areas as textiles or 'rare earths'. Equally, where there has been a significant security concern as part of the relationship, this has often proved to be intractable- the most obvious example being that of energy relations with the Russians - and none of the partnership negotiations have shown the EU able to incorporate major security concerns. Increasingly, development policy has become an area of competition between the EU and its potential strategic partners, the most salient case being that of sub-Saharan Africa, as already noted. EU efforts to arrive at understandings with the Chinese and others - and thus to defend what had previously been seen as almost a domaine réservée-have had relatively little concrete payoff. As already noted, energy relations with the BRIC countries have become sensitive in a variety of ways, and have also become linked with environmental concerns - the Chinese opposition to the extension of the EU's emissions trading scheme to passenger aircraft originating outside the EU being a classic example of the kind of linkage that may or may not be intended and certainly poses major problems of diplomatic management. ${ }^{28}$ The rhetoric and the reality of strategic partnership are thus often widely distanced from one another. The lesson appears to be that when efforts are made to go beyond the rhetoric and the comforting general sentiments to negotiate material obligations and commitments — whether these are in the security or the welfare sphere - things become much more difficult. It is also clear that from the EU perspective there is a tension over ownership of strategic partnerships: while it seems clear that the President of the European Council and the HRVP are key actors in the general negotiations, the more specific commitments are often very largely within the domain of the Commission, and to be even more specific, that of the Directorate General for

\footnotetext{
${ }^{28}$ See Jing Men, 'Challenges to the EU-China strategic partnership', EU-China Observer, no. 6, 2012, pp. 4-9.
} 
Trade. ${ }^{29}$ So there is tension between economic and broader diplomacy that is particularly brought out by commercial negotiations. In the case of China, this has even been institutionalized at the top level with the development of two separate highlevel dialogues, one on economic and financial questions and one on political and security questions. There is of course a further important and potentially disabling tension — between EU diplomacy and the national diplomacies of member states— that affects both the commercial and the security sphere, and which is exacerbated by the very significance of the BRICs to particular groups of member states. In relation to Russia and China in particular, this can lead to major elements of fragmentation around an apparent commitment at the rhetorical level to common EU positions. ${ }^{30}$ No clearer specific example can be found than the apparent abandonment of a collective EU position on economic relations with China by the German government, epitomized by Chancellor Merkel’s visit to Beijing in the autumn of 2012. What this means is that 'strategic partnerships' as a diplomatic strategy on the part of the EU face important if not insurmountable obstacles. These arise in part from the development of the Union itself, and especially from the continuing impact of the financial and economic crisis. But, as pointed out in recent studies, they also reflect two further factors: on the one hand, the disparity between perceptions of the EU's role as a diplomatic actor in Brussels and perceptions in national capitals within the Union; and on the other hand, the diminishing expectations held of the EU as a potential partner by rising powers. ${ }^{31}$ The two factors are of course linked in an objective sense, and increasingly they are linked in the minds of policy-makers acting on behalf of the rising powers themselves, where they interact with the material and

\footnotetext{
${ }^{29}$ Author's interviews with European External Action Service, Cabinet of the President of the European Council and European Commission, Nov. 2011-Feb. 2012. 30 These tendencies to fragmentation are well brought out in a study of EU-China relations: J. Fox and F. Godement, A power audit of EU-China relations (London: European Council on Foreign Relations, 2009). On EU-Russia relations, see Hiski Haukkala, The EU-Russia strategic partnership: the limits of post-sovereignty in international relations (London: Routledge, 2010).

${ }^{31}$ See Grevi and Renard, eds, Partners in crisis; Renard and Biscop, eds, The EU and emerging powers.
} 
ideational aims of those powers. This is not a promising foundation from which to pursue new strategic initiatives on behalf of the EU.

Many of the attempts made by the EU to forge strategic partnerships as instruments of containment or management have what can be termed a 'bi-multilateral' dimension. ${ }^{32}$ In other words, they affect and are affected by parallel negotiations at the interregional or broader multilateral levels — a feature which increases their complexity and intractability, but which might also be used to advantage if handled appropriately. In the case of interregional relations, there has been a consistent attempt by the EU to embed bilateral partnerships in broader intercontinental frameworks, and also to use those frameworks as a means of injecting EU influence into the regions where the BRICs are dominant. ${ }^{33}$ Thus, relations with China (and now with India and Russia) are in principle surrounded by the Asia-Europe Meeting; those with Brazil are embedded within EU relations with Latin America and in a more restricted sense with MERCOSUR; and those with Russia are located within a number of European and Eurasian security and commercial frameworks. Competition with rising powers - and to a degree with established powers such as the United States-in areas such as sub-Saharan Africa is at least in part expressed through the EU's search for regional partners, for example through the Economic Partnership Agreements that are part of the Cotonou Convention. But in all of these cases, there is a question about the extent of the commitments undertaken and about the ways in which-if at allthey might displace or shape bilateral relationships. In an ideal world of EU diplomacy as seen from Brussels, one suspects there would be a neat division of labour between bilateral, interregional and multilateral institutions, all susceptible to management by the EU in accordance with well-understood rules. Such a world

${ }^{32}$ For a discussion of 'bi-multilateral' negotiations, see Michael Smith, 'The European Union and the United States of America: the politics of "bi-multilateral" negotiations’, in Elgström and Jönsson, eds, European Union negotiations, pp. 16482.

33 See Keukeleire and Bruyninckx, 'The EU, the BRICs and the emerging new world order'; also Alan Hardacre, The rise and fall of interregionalism in EU external relations (Dordrecht: Republic of Letters, 2009); Alan Hardacre and Michael Smith, 'The EU and the diplomacy of complex interregionalism', The Hague Journal of Diplomacy 4: 2, Sept. 2009, pp. 167-88. 
would demonstrate the utility of soft balancing mechanisms, through which the EU could enter into the power dynamics of specific regions and frame regional agendas without having an established or material presence beyond its undoubted commercial concerns. But, as pointed out earlier, that is precisely the kind of well-ordered world in which we do not live now and in which we will not be living for the foreseeable future. As a result, it is markedly less likely that the $\mathrm{EU}$ will be able to penetrate a number of regional arenas, not least because of their increasing focus on the regional power preoccupations of precisely those rising powers that the EU might wish to 'contain'. Not only this, but the appeal of the EU as an extraregional partner has been tarnished by its internal economic and financial travails, and by the questioning of the European 'model' even within Europe itself.

The broader multilateral system is key to the background against which the EU's bilateral and interregional diplomacy operates, and thus also to the potential for the furthering of negotiated order in the world arena. As noted earlier, one image of the EU is as a compulsive multilateralist, reflecting the benefits it has undoubtedly harvested from the existing mechanisms of global governance. These benefits are partly material, for example in terms of commercial advantage and the construction of beneficial international regimes; they are also to be found in terms of legitimacy and status, intangible but powerful contributions to the image of the EU as a global actor and to the propagation of European values. The Union has tied its diplomacy tightly to central elements in the multilateral system for these reasons-predominantly in the economic and social spheres, but increasingly in the security domain, and particularly in the latter case to the United Nations system. Hence the intense efforts by the EEAS to ensure 'enhanced observer' status in the UN General Assembly, and the explicit linking of EU efforts in such areas as non-proliferation to UN mandates and frameworks. $^{34}$

How effective has the EU been as a multilateralist, in using the global multilateral system as a means not only of enhancing its own status but also of bringing rising

\footnotetext{
${ }^{34}$ On this general issue, see e.g. Katie Verlin Laatikainen and Karen Smith, eds, The European Union at the United Nations: intersecting multilateralisms (Basingstoke: Palgrave Macmillan, 2006); Knud Erik Jørgensen and Katie Verlin Laatikainen, Routledge handbook on the European Union and international institutions: performance, policy, power (London: Routledge, 2013).
} 
powers into acceptable frameworks for international regulation and stability? The two elements of the question are inextricably linked, since the European project until the 1990s undoubtedly benefited from the legitimacy and status accorded it by a range of multilateral bodies; since the late 1990s, however, the record has been very mixed, and the trend has turned against the EU in some important ways. In terms of security, the EU has maintained its close linkage with UN mandates but has increasingly appeared as a kind of subcontractor to the UN in conflict areas, as well as taking an active role in promoting measures in areas of non-military security. In conflicts where rising powers have had a major stake, or have not wanted bodies such as the UN to get involved, the EU has not been able to change the calculus. Commercial policy, as might be expected, shows a more positive picture in the sense that the EU has been able to facilitate the engagement of BRIC countries (specifically China in 2001 and Russia in 2012) in the WTO and other related institutions-but once involved (and remember that some of them have been involved for a very long time) they have not necessarily been responsive to EU negotiating demands. In fact, as the fate of the Singapore issues in the Doha Round demonstrates, the opposite has often been the case, and the newly arrived BRICs (in this case China) have been active in resisting EU initiatives. Development policies have become an area of open competition between the EU, the US and the BRICs, with other regional competitors joining the fray and markedly different models both of development and of assistance being promulgated. While for a moment in the early 2000s the environmental domain might have been seen as an area of EU leadership, the lesson once again seems to be that once the rising powers become interested enough, they can do a lot to thwart the EU's desire for negotiated order solutions_-and that they may have markedly different priorities from those espoused in the EU model for environmental protection. ${ }^{35}$ Where the existing multilateral institutions are feeble, as in the case of energy and energy security, the EU has little on which to base a set of proposals for negotiated order-a state of affairs underlined by the lack of consensus within the EU on key issues and relationships in the energy sphere. And global financial management through the G20,

\footnotetext{
${ }^{35}$ See e.g. John Vogler, 'The challenge of the environment, energy and climate change', in Hill and Smith, eds, International relations and the European Union, pp.
} 349-79. 
which might be a channel for the pursuit of 'effective multilateralism', ${ }^{36}$ cannot be an area of major EU influence as long as its member states are paralysed in the face of the eurozone sovereign debt crisis. Tellingly, although the United States is a key actor in each of the areas outlined here, there has been little in the way of explicit coalitionbuilding between the EU and the US, with the (less than positive) exception of the Doha Round during the mid-2000s. Such a judgement might be modified in the light of the new impetus in early 2013 towards negotiation of an EU-US free trade agreement, but those negotiations will be taxing in themselves even before their implications for broader global governance issues are taken into account. These conclusions link directly with the points noted earlier about the variations in the efficacy of EU negotiating initiatives across different 'sites' of negotiation and domains of activities.

A number of key problems can be identified in the EU's response to the challenge of the rising powers, and especially in its attempts to achieve an enhancement of global negotiated order through diplomacy. Briefly, they may be summarized as follows. First, there have been challenges to the capacity to pay attention and to mobilize resources for effective diplomatic influence. These are linked to problems of coordination and coherence, in areas where bilateral, interregional and multilateral negotiations are often inextricably connected. Alongside these issues, there is clear evidence of 'leakage' of activity and influence to member states, in both political and economic issue areas, reflecting dispersion of preferences and the persistence of national diplomacies. This in turn intersects with loss of credibility because of the internal challenges to the European model, and the related inability to muster sufficient diplomatic and material resources (for example in development policy). Not surprisingly, the EU has demonstrated a degree of normative confusion when confronted by alternative models of security, development, global governance and other aspects of the rising power phenomenon. Each of these areas of challenge contributes to loss of capacity to frame issues of global governance and to form coalitions in the new power constellations (although there is probably more of an implicit coalition with the United States at present than there has been previously in a number of areas). Finally, the EU has proved unable to embed its preferred

\footnotetext{
${ }^{36}$ Juha Jokela, The G-20: a pathway to effective multilateralism?, Chaillot Paper no. 125 (Brussels, European Union Institute for Security Studies, April 2011).
} 
approach — integrative, value-creating — to the handling of relations with BRIC countries, largely as a reflection of the above factors. This is not a comfortable position for the continued conduct of EU diplomacy towards rising powers, and it directly contributes to continuing uncertainty about the EU's capacity to take responsibility, exercise leadership and build a stable role through its diplomacy towards rising powers in particular and global governance more generally.

\section{Conclusion}

At the beginning of this article, three observations were made about the nature of EU diplomacy in the current period. First, the EU had spent a lot of time and effort equipping itself with the tools with which to frame and conduct a coordinated approach to external action and diplomacy. Second, a predominant end of the external projection of EU diplomacy has been the promotion of negotiated order as an approach to the management of the world arena. Third, the EU's approach and actions are now under question and challenge as never before, thanks to a concatenation of internal and external forces that has thrown into question the EU's capacity to adapt to and profit from a reshaped world arena. As a corollary to these observations, it was also noted that there was a continuing tension in some areas between the EU and 'Europe', specifically reflecting the uneasy fit between EU institutions and aspirations and those of the EU's member states.

The argument in the article has proceeded on the basis of those initial observations and the questions to which they give rise. It has pointed out the continuing uncertainties about the foundations and status of the EU's system of diplomacy, the complexity and diversity of the challenge posed by the rising powers in a turbulent global arena, and the unevenness of the EU's diplomatic response in a context where an effective 'full spectrum diplomacy' is called for. Rather than rehearsing the conclusions to individual parts of the article in detail here, I want to conclude by making three further observations. First, the argument advanced in the past, that success in the diplomatic field and the use of diplomatic status acts as an 'antidote' for the travails of the EU's internal processes, is no longer available, since the EU's diplomacy faces intractable problems of its own and is radically constrained by internal crisis. Second, the scope and scale of the external challenge from rising powers is such as to strain to the limit the capacity of the EU's diplomacy, and at the same time the credibility of the EU as an international actor is undermined both materially and ideationally by the continuing internal crisis of the European project. 
Finally, the EU in this context does not have the power to frame international negotiations or to ensure integrative, value-adding outcomes for negotiations, even in areas where it is well established. Whereas there was a time in the late 1990s where the EU could claim to have this power, that time has gone, and we are now in a much less hospitable environment for the EU. In short, to reiterate a claim made at the beginning of the article, the EU is now a long way outside its comfort zone, and it is difficult in current circumstances to see how it can retrieve the situation. Making the attempt is important; but the chances of doing so in the short or medium term are small. 